\title{
INTELEKTUALIŚCI TOTALNI JAKO PRZEDSTAWICIELE INTELIGENCJI - TEORIA WARSTWY „WZGLĘDNIE ODERWANEJ” KARLA MANNHEIMA
}

Jan Kozubowski

Uniwersytet Warszawski

\section{/// 1. Wstęp - pojęciowa niejednoznaczność}

Karl Mannheim zgadzał się z zasadniczą tezą Maxa Webera o kroczącej kapitalistycznej racjonalizacji, której społecznym skutkiem okazał się światopoglądowy politeizm. Uniwersalność prawdy została podważona przez pluralizm stanowisk epistemicznych. W tym zrelatywizowanym świecie Karl Mannheim próbował znaleźć wyznacznik historycznej obiektywności. Do jej określenia predestynowana została cała grupa społeczna - intelektualiści. Socjologia wiedzy odkryła historyczne warunki wyróżniające tę grupę, które umożliwiają jej reprezentację interesów całego społeczeństwa. Tę epistemicznie „uprzywilejowana”” warstwę Mannheim nazwał ,względnie oderwaną inteligencją". Oprócz kontrowersji, jakie wywołała sama treść teorii socjologa, budzi ona również wiele wątpliwości metodologicznych. Warto więc od nich rozpocząć niniejszy artykuł.

Konieczne wydaje się uporządkowanie pojęć, których używa Mannheim przy omawianiu problemu inteligencji. W czasie lektury prac socjologa poświęconych temu tematowi od razu rzucaja się w oczy dwie kwestie. Po pierwsze, w żadnej z tych prac Mannheim nie rozróżnia znaczenia takich pojecc, jak „intelektualista” i „inteligent”. Po drugie, socjolog nie precyzuje, na jakim poziomie agregacji przeprowadza swoją analizę. Czy koncentruje 
się na indywidualnym intelektualiście, czy na całej grupie społecznej intelektualistów? Problemy te wynikają z niedookreślenia pojęć przez samego autora. Uczynione przeze mnie w tym podrozdziale klasyfikacje są w pewnej mierze sztucznymi zabiegami, wyrażaja jednak intuicje Mannheima i opierają się na jego bardziej ogólnych tezach - przede wszystkim tych dotyczących metodologii socjologii wiedzy.

Na podstawie pism Mannheima nie można rozwiać pierwszej wątpliwości (zob. Peciakowski 2016: 267). Warto jednak zauważyć, że odnosząc się do sytuacji społecznej całej grupy, autor używa pojęcia „inteligencja” lub „intelektualiści”, zaś kiedy charakteryzuje indywidualnego członka tej grupy, pisze o „intelektualiście”. Może to wskazywać na silnie indywidualizujący charakter pojęcia intelektualisty (denotuje członka grupy w pewien sposób wyróżnionych jednostek, zob. tamże: 271). Taka intuicja koresponduje z etymologiczna różnicą między tymi dwoma pojęciami. Na arenie historii intelektualista pojawił się dużo wcześniej niż inteligent. Słowo „intelektualista” ma francuskie pochodzenie (intellectuel) i użyte zostało po raz pierwszy już w XIII wieku, przyjęło się następnie na Wyspach Brytyjskich jako intellectual. Zaczęło wówczas oznaczać „osobę posiadająca [...] ponadprzeciętne zdolności umysłowe" (tamże: 262). Pierwotnie używano go tylko w liczbie pojedynczej: opisywało konkretna jednostkę posiadająca wybitne predyspozycje intelektualne. Z kolei powstanie inteligencji wiązano z kapitalistycznymi makroprzemianami, którym uległy peryferyjne społeczeństwa wschodnioeuropejskie w XIX wieku (zob. Chałasiński 1946: 29). Od poczatku swojego powstania słowo ,inteligencja” odnosiło się do pewnej grupy społecznej. Po raz pierwszy zostało użyte przez polskiego filozofa Karola Libelta w 1844 roku, który pisał o „inteligencj[i] narodu” polskiego (Walicki 2011: 17). Z języka polskiego i rosyjskiego pojęcie to powędrowało na Zachód (tamże: 9-10). W połowie XIX wieku pojawiło się w Niemczech jako intelligenz, na przełomie wieków powrócił do niego Alfred Weber (Peciakowski 2016: 266), brat Maxa Webera.

Historia tych dwóch pojęć wywarła ogromny wpływ na ich konceptualizację we współczesnej teorii socjologicznej. Obecnie wyróżnia się zwykle intelektualistów jako „tę część inteligencji, która zajmuje się twórczością artystyczną wszelkiego rodzaju, twórczością naukowa, ideologiczną i filozoficzną" (Szczepański 1991a: 127). Z kolei inteligencja jest szersza kategoria - obejmuje ludzi, którzy w wyniku nabycia wykształcenia zdobyli umiejętność władania rozumem (Szczepański 1991b: 112), jest to grupa ludzi kulturalnych, często wykonujących wolne zawody, posiadających pewien uniwersalny poziom wiedzy. Intelektualistami można zaś nazwać naj- 
wybitniejsze jednostki, które mają ogromny wpływ na samą treść tej „uniwersalnej" wiedzy (por. Epstein 2018: 6; Sadri 1992: 69). W artykule o historii rosyjskiej inteligencji Mikhail Epstein wskazuje, że „[i]ntelektualizm to misja, system kreatywnych, publicznych i moralnych wartości” (2018: 7). Według autora cechą intelektualizmu jest selektywność treści: „[s] łowo «intelekt» ma etymologiczne powiązania ze słowem «pomiędzy» i dosłownie znaczy «czytać pomiędzy, wybierać między»" (tamże: 7). Inteligencja jest odbiorcą treści sformułowanych przez intelektualistów. Henryk Domański podsumowuje: ,[e]litą inteligencji są intelektualiści” (2008: 13).

Mannheim najprawdopodobniej znał omawiane rozróżnienie, przemawia za tym fakt, że - jak wskazuje Ahmad Sadri - jest ono zgodne z teorią Maxa Webera (Sadri 1992: 70). Pisma Webera stanowiły zaś jedno z najważniejszych źródeł inspiracji socjologicznych dla Mannheima. Aby unaocznić różnicę między tymi dwoma grupami społecznymi, Sadri proponuje wykorzystanie podziału, który Weber przedstawił w Polityce jako zawodzie i powołaniu. Inteligencje przyrównuje Sadri do tych, którzy żyja „z” polityki, zaś intelektualistę do kogoś, kto żyje „dla” polityki (1992: 119). Analogicznie można więc powiedzieć, że intelektualiści żyja „dla” nauki, nie zaś „z” nauki.

Wracając do teorii Mannheima: przyjmuję definicje „intelektualisty” zaproponowana przez Hansa Speiera. Autor jest przekonany, że zostałaby ona zaakceptowana przez samego Mannheima: intelektualiści są warstwa inteligencji, która wykonuje - słowami Alfreda Webera - pracę intelektualną (Speier 1990: 215). Nawiązanie do Alfreda Webera wydaje się oczywiste, albowiem to od niego Mannheim przejął termin „względnie oderwanej inteligencji” (2008: 189). W Weberowskiej charakterystyce pracy intelektualnej w oczy rzuca się jej wyjątkowy charakter:

Nie jesteśmy zainteresowani jakąkolwiek pracą, którą wykonuje się używając do tego intelektu, chodzi nam tylko o taką pracę, która odnosi się do intelektu samego w sobie, do uniwersalnego ducha, który konstruuje kontekst, do generalnego uniwersum, które kształtuje naszą egzystencję, stanowi podstawy naszego państwa i społeczeństwa. Nie tylko jest to duchowa podstawa naszego istnienia, ale jest to najwyższa duchowa ekspresja naszej egzystencji (Speier 1990: 212).

Poprzez swoją wolną pracę intelektualiści tworzą więc całościowy klimat epoki, doprowadzają do kulturowej syntezy sprzecznych żywiołów 
społecznych, tym samym wznoszą swoją wiedzę na poziom uniwersalnego ducha. Do tych wybitnych jednostek Alfred Weber zaliczał przede wszystkim „pisarzy, dziennikarzy, artystów, akademików, wyższych urzędników [...]" (Speier 1990: 212). Widać więc, że to właśnie od Webera Mannheim przejął tak silny nacisk na wyjątkowość (profetyczność) intelektualistów.

Wiedząc, że w teorii Mannheima mamy do czynienia z intelektualistami wykonującymi pracę intelektualną, można przejść do drugiego zadanego na wstępie pytania: czy ta Weberowska wyjątkowość przypisana zostaje intelektualiście czy całej grupie społecznej? Podstawową jednostką analizy w teorii Mannheima jest grupa społeczna. Socjolog krytykuje nominalizm Maksa Webera i wielokrotnie wskazuje, że grupowa świadomość i kontekst społeczny determinują światopogląd jednostki (Mannheim 2008: 33). Z drugiej jednak strony, opisując kondycję inteligencji, Mannheim często przeprowadza analize jednostkowa: wspomina o obowiązkach intelektualisty oraz analizuje skutki psychiczne, jakie wywołuje jego sytuacja społeczna. Problem ten można rozwiązać, odwołując się do dwóch podstawowych elementów teorii Mannheima: koncepcji „inteligencji”/,intelektualistów” oraz „totalności”.

Pojęcie totalności, które zostanie omówione w niniejszym artykule, odnosi się do historycznej prawdy (prawdy właściwej dla każdej epoki), do synoptycznego obrazu społeczeństwa, w którym każdy pojedynczy przypadek wpisany zostaje w całościowy kontekst. Z poziomu totalności widać wyraźnie, że każdy grupowy światopogląd jest poznawczo ograniczony. Mannheim w żadnej ze swoich prac nie użył terminu ,intelektualista totalny", jednak łącząc dwa wyżej wymienione elementy, można sformułować Mannheimowską teorię intelektualistów totalnych. W tym przypadku podstawowa wątpliwość sprowadza się więc do pytania: czy jednostka (intelektualista) może zapewnić sobie dostęp do totalnego obrazu społeczeństwa, czy taka możliwość zarezerwowana jest wyłącznie dla grupy wybranych intelektualistów?

W Ideologii i utopii autor przedstawia proces uświadamiania sobie przez pojedynczego intelektualistę swojego miejsca historycznego. Ulega on olśnieniu („punkt zwrotny”): zdaje sobie sprawę, że jego światopogląd jest tylko jednym $z$ wielu wyznawanych społecznie systemów wartości. Wraz z usytuowaniem swojej partykularnej ideologii w mgławicy walczących ze sobą światopoglądów (Mannheim 2008: 138-139) wyzwala się on od determinującego wpływu grupy społecznej na swoje działanie. Taka jed- 
nostkę nazywam ,intelektualistą totalizującym”1. Jak wskazuje Mannheim, wykazuje on „intencję całościową" (2008: 139) - pociąg do dogłębnego analizowania sytuacji społecznej. Dążenie do rozumowego wychodzenia poza konkretne sytuacje oraz analizowania ich w odniesieniu do większej całości należy do sfery wolicjonalnej, jest subiektywnym wyborem jednostki, która np. pragnie poszerzyć swoją wiedzę. Stanowi pierwszy krok poczyniony w kierunku totalności: jednostka jest jednak zbyt małym ogniwem społecznej machiny, aby móc dostrzec wszystkie mechanizmy rządzące życiem społecznym. Klucz do poznania społeczeństwa jako całości maja tylko intelektualiści - grupowo. Można ich więc bez wahania nazwać „,intelektualistami totalnymi”, składają się na nich intelektualiści totalizujący. Wyjątkowe umiejętności epistemiczne tej grupy są obiektywnym skutkiem subiektywnej (jednostkowej) intencji całościowej każdego z intelektualistów - są wypadkową wielu subiektywnych dążeń do totalności.

Już na tym wstępnym etapie analizy teorii Mannheima widać, że znacznie różni się ona od koncepcji intelektualisty totalnego Pierre’a Bourdieu. W centrum uwagi autora Regut satuki znajduje się bowiem wybitna jednostka - Jean-Paul Sartre, zaś określenie „intelektualista totalny” ma nacechowanie raczej pejoratywne (wykazuje wartościujący stosunek autora do przedmiotu). Służy jako narzędzie do demaskacji działań egzystencjalisty, który poprzez swoje wszechstronne zaangażowanie akumuluje władzę społeczna. Z kolei w teorii Mannheima wyróżniona zostaje przede wszystkim grupa intelektualistów, która postrzegana jest przez autora pozytywnie (choć w założeniu pojęcia ,intelektualista” czy ,inteligencja” mają być wolne od wartościowania). Mannheimowska totalność nie odnosi się do wszechstronnej działalności intelektualisty na wielu polach społecznych (jak u Bourdieu), ale jest za to wyznacznikiem obiektywności.

Podsumowując powyższe wyjaśnienia: przyjmuję, że posiadanie statusu inteligenta jest warunkiem koniecznym, ale niewystarczającym do nadania jednostce miana intelektualisty. Intelektualiści totalizujący składaliby się na tę część inteligencji, która rzeczywiście pozostaje społecznie nieprzywiązana, a jak wskazuje Mannheim, jest to specyficzna i nieliczna grupa wśród całej warstwy inteligenckiej (Pels 2003: 81, por. Peciakowski 2016: 266). Głównym celem niniejszego artykułu jest scharakteryzowanie tej wybranej grupy w kontekście teorii Mannheima, dlatego nawet jeśli w dalszej części pracy używam terminu „inteligencja”, odnosi się on do tej

${ }^{1}$ Mannheim nigdy nie użył ani tego pojęcia, ani pojęcia „intelektualiści totalni”. Są to terminy sformułowane przeze mnie, oparte na teorii socjologa. 
wąskiej części inteligencji - intelektualistów totalnych, których nazywam też po prostu ,intelektualistami”.

Tak więc nie każdy inteligent jest intelektualistą, co nie zostało jednak wyrażone przez socjologa explicite. Aby możliwe stało się poznanie społecznego interesu całości, spełnione muszą zostać konkretne obiektywne warunki historyczne (powstanie warstwy inteligenckiej), ale pojawić się musi również subiektywne dążenie członka inteligencji do odnalezienia tej obiektywności (działanie należące do sfery wolicjonalnej). Niczym marksistowski proletariat intelektualiści doprowadzają do syntezy tych dwóch sfer historii. Najważniejszym (obiektywnym) skutkiem procesu historycznego okazuje się alienacja inteligencji, a więc jej izolacja od codziennych problemów społeczeństwa klasowego. Dzieje się to za sprawą zdobycia nowoczesnego wykształcenia przez jednostkę. Wykształcenie sprawia również, że wspólnota zaczyna uważać intelektualistę za element sobie obcy. W artykule analizuję ten proces przez pryzmat sławnego eseju Georga Simmla pt. Obcy. Intelektualista może próbować sztucznie osłabić to bolesne uczucie obcości, przyłączając się do danej klasy społecznej. Rezygnuje on jednak wówczas ze swojej profetycznej roli. Żeby spełnić swoje posłannictwo, musi pogodzić się ze swoją obcością, a nawet powinna być ona jego wolnym wyborem. Musi zdać sobie sprawę ze swojej pozycji społecznej i wykorzystać alienacje jako środek do całościowego zbadania rzeczywistości społecznej. Grupowa pozycja „vis a vis” totalności pełna jest paradoksów, które odciskają swoje piętno na psychice pojedynczego intelektualisty. Wynika to m.in. z faktu, że jest on podmiotem wewnętrznie rozdartym: zdaje sobie sprawę zarówno z konieczności obserwacji życia społecznego (co wiąże się - słowami Györgya Lukácsa - z podejściem kontemplacyjnym do świata), jak i z potrzeby działania praktycznego. Obserwacja życia społecznego musi mieć charakter naukowy. Mannheim znalazł wyznacznik weberowskiej obiektywności (zarazem nadając inne znaczenie temu pojęciu) po stronie przedmiotowej, w sferze niezależnej od indywidualnego poznającego podmiotu. Tym wyznacznikiem jest właśnie świadomość intelektualistów totalnych. Obiektywność zostaje „wykuta” w ramach walki społecznej, jest względnie autonomiczną duchową całością. Nie jest to obiektywność, którą może dostrzec Weberowski naukowiec po spełnieniu pewnych podmiotowych warunków (m.in. stosowania racjonalnych pojęć-narzędzi). Właśnie dlatego stosunek Mannheimowskiego intelektualisty do świata sytuuje się między „,marksistowskim zaangażowaniem a weberowską bezstronnością" (Pels 2003: 89). 
Warto również zaznaczyć, że teoria Mannheim ewoluowała w trakcie jego kariery naukowej: we wczesnej Myśli konserwatywnej inteligencja postrzegana jest jako sługa danej klasy, który uduchawia jej społeczną walkę; w Ideologii $i$ utopii przedstawiona została optymistyczna wizja społecznych zdolności intelektualistów, którzy stopniowo zmieniaja politykę w naukę; z kolei w pismach późniejszych optymizm maleje, głównym zadaniem inteligencji staje się przebudowa sfragmentaryzowanego społeczeństwa.

\section{/// 2. Walka świadomości}

Według Mannheima świat społeczny jest areną niekończących się walk antagonistycznych systemów symbolicznych, a nasze światopoglądy kształtują się zawsze w opozycji do ideałów innych ludzi (koresponduje to z pogladami Webera, zob. tegoż 1985: 51). Różnice w ontycznym umiejscowieniu aktorów powoduja, że ich światopoglądy są ze sobą niekongruentne, pełne nieredukowalnych różnic. Każda grupa społeczna (a Mannheim mówi w tym kontekście przede wszystkim o klasach, choć nie tylko, zob. Mannheim 1993: 72) spogląda na rzeczywistość z konkretnego miejsca w systemie społecznym, co ogranicza jej zdolności poznawcze: może dostrzec jedynie pewien wycinek większej całości, jaką jest społeczeństwo. Mannheim klasyfikuje te różne grupowe interpretacje rzeczywistości w dwa metatypy świadomości „transcendentnej wobec bytu”: ideologie i utopie. Autor nazywa te wyobrażenia transcendentnymi, albowiem są one niezgodne z rzeczywistym poziomem rozwoju społeczno-gospodarczego, a więc słowami socjologa - z „działającym porządkiem życia” (Mannheim 2008: 231, zob. Bauman 2010: 105) - bytem. Mannheim nie uważa jednak, że społeczna świadomość jest po prostu fałszywa, a aktorom coś uniemożliwia dostrzeżenie czystych faktów (2008: 135). Byt nie jest przez socjologa postrzegany statycznie, ale jest ciagłym procesem historycznym, stawaniem się, syntezą (zob. Wójcik 2014: 50-51). Wydaje się, że w teorii Mannheima żadna grupa społeczna nie ma możliwości dostrzeżenia bytu bez jakiejś mediacji, zapośredniczenia. Naturą klasowego światopoglądu jest perspektywiczność:

Żadna warstwa społeczna, żadna klasa nie jest nośnikiem całego ruchu; nie jest również uzasadnione ocenianie tego globalnego procesu jedynie pod kątem wkładu jednej klasy. Być może rzeczywiście jedna klasa niesie, że tak powiem, „leitmotiv” ewolucji, ale 
harmonię całości można uchwycić, biorąc pod uwagę cały kontrapunktowy wzór wszystkich głosów (Mannheim 1952: 125).

Z powyższego cytatu można wywnioskować, że mamy w rzeczywistości do czynienia z dwoma typami „całości” społecznych: pierwsza z nich jest ogólną strukturą składająca się $z$ antagonistycznych części, można ją więc nazwać „całością uniwersalna” (lub po prostu - totalnością społeczeństwa). Z kolei druga - „całość partykularna” - jest dostępnym danej klasie wycinkiem rzeczywistości społecznej, lokalnym „światem” danej grupy, który jedynie w ramach jej świadomości ulega uniwersalizacji. Wiele takich poznawczo ograniczonych światopoglądów składa się na ,uniwersalną całość" - społeczeństwo, w którym zawsze dominuje pewna klasa społeczna. Urządza ona świat według swojego partykularnego interesu. Mannheim zauważa jednak, że jest pewna grupa społeczna, która patrzy na rzeczywistość z szerszej perspektywy, a na dodatek nie dąży do przejęcia władzy w społeczeństwie. Jej specjalna pozycja jest wynikiem procesu historycznego, który w pewnym stopniu pozbawił ją klasowego charakteru. Ta grupa to „społecznie oderwana inteligencja” (Mannheim 2008: 189). Intelektualiści wymykają się klasowej kategoryzacji, ponieważ najczęściej pochodzą z bardzo różnych kręgów społecznych, a ich środowisko cechuje się skrajną heterogenicznością. Jak zaznacza Speier, niejednolity charakter tej warstwy wynika z faktu, że „każda klasa posiada swoją inteligencję” (1990: 209). Staje się więc jasne, że Mannheim chciał stworzyć teorię, która byłaby w stanie opisać i wyjaśnić tak różne przypadki intelektualistów, jak np. inteligenci proletariaccy (György Lukács) czy inteligenci „klasy panującej” (Max Weber). Koncepcja Mannheima opiera się więc na spostrzeżeniu, że „[s]ą intelektualiści, którzy są robotnikami, i intelektualiści, którzy są Junkrami” (Speier 1990: 210).

Społeczne oderwanie inteligencji jest cechą nowoczesności. Przez wieki powszechna praktyką było angażowanie się intelektualistów w partykularne walki świadomości. Mannheim opisuje tę ich pierwotną rolę w swojej wczesnej pracy pt. Myśl konserwatywna. Według autora historyczne zadanie myślicieli sprowadzało się - parafrazując Jana Jakuba Rousseau - do przyozdabiania bezosobowych interesów klasowych girlandami kwiatów (1956: 11), ideologowie byli więc w stanie uzasadnić dowolne działanie wybranej przez nich klasy (Mannheim 1986: 78, por. Kozubowski 2018: 60). Jednak już w swoim opus magnum - Ideologii $i$ utopii - socjolog zaznacza, że współcześnie mamy do czynienia z procesami, które alienują intelektualistę od społeczeństwa. Nabiera on dystansu do jednostronnych rozwiązań i gru- 
powych sporów, co pozwala mu na dostrzeżenie powiązania między światopoglądem danego aktora a jego umiejscowieniem społecznym. Staje się więc krytyczny wobec wszelkich dyskursów, które z partykularnej perspektywy zgłaszaja roszczenia do przebudowy „,całości uniwersalnej”, zdaje sobie bowiem sprawę, że „,...] dyskusje teoretyczne można traktować jako incydenty ogólnej walki o władzę" (Kecskemeti 1952: 25). On znajduje się poza tą walką: wiedza nie jest dla niego środkiem do zdobycia społecznej dominacji - w tym sensie świadomość Mannheimowskiego intelektualisty totalizującego jest pozaideologiczna. Socjologia wiedzy uwidacznia mu partykularność wszelkich dyskursów partyjnych, dlatego np. marksizm nie może być dla niego dobrym wyborem. Jest to bowiem ideologia „relatywnie adekwatna" do sytuacji proletariusza (Mannheim 1993: 75, por. tenże 1986: 27). Nie może ona jednak wytłumaczyć wszystkich społecznych fenomenów. Mimo to intelektualista nie wyzbył się całkowicie swoich klasowych cech: nie może się całkowicie odciąć ani od swojego pochodzenia, ani od społeczeństwa w ogóle. Dlatego Mannheim wskazuje, że inteligencja jest nieprzywiązana (w angielskim tłumaczeniu: free-floating) względnie (zob. Loader 2016: 53) - wywodzi się z konkretnych środowisk klasowych, ale nabiera do nich dystansu. Widać więc wyraźnie, że to sam przedmiot teorii „relatywnie oderwanej inteligencji” (relativ freischwebende Intelligenz) (Mannheim 1956: 106) zmusza Mannheima do ambiwalencji w stosunku do preferowanego poziomu analizy (indywidualnego/grupowego). W myśl koncepcji badacza ,inteligencja była homogeniczna i heterogeniczna jednocześnie" (Loader 1997: 226); intelektualistów bardzo wiele różni (wspomniane pochodzenie klasowe), sa jednak na tyle do siebie podobni, że można ich wyodrębnić jako osobna grupę społeczną. Pomocne w zrozumieniu relacji między jednostką a grupa okazuje się w tym przypadku rozróżnienie, które w pismach Mannheima odnalazł Colin Loader. Socjolog wyróżnia dwa typy społecznego usytuowania podmiotu: może być on „egzystencjalnie powiązany” - „existentially connected (seinsverbunden)” bądź „egzystencjalnie przyporządkowany” - „existentially bound (seinsgebunden)” (Loader 1997: 225, por. tenże 1985: 112). Pierwszy typ związku ze światem ma charakter bardziej ogólny i odnosi się do wszelkich zjawisk kulturowych - oznacza po prostu powiązanie podmiotu z większą społeczno-kulturową całościa, m.in. ze środowiskiem, w którym żyje. Nie wyraża relacji kauzalnej. Z kolei drugi termin, który pojawił się w Ideologii i utopii, wskazuje na poznawcze ograniczenie podmiotu (partykularność jego światopoglądu). Opisuje relacje kauzalna: konkretne uwarunkowanie bytowe danego aktora jest przyczyną ograniczoności jego światopoglądu. Loader zauważa, że „względne 
oderwanie" intelektualistów zaprzecza ich egzystencjalnemu przyporządkowaniu, nie wyklucza jednak ich egzystencjalnego powiązania: ,[...] egzystencjalne powiązanie jednostek pozwala grupie inteligencji być oderwaną. Indywidualne powiązanie oznacza grupową heterogeniczność grupy" (Loader 1997: 227). Występujące między intelektualistami różnice w pochodzeniu, w poglądach, w stosunku do świata sprawiają, że w ramach ich wewnątrzgrupowych starć ideologicznych reprezentowany jest głos każdej części społeczeństwa.

Widać więc wyraźnie, że wiele społecznych czynników różnicuje wewnętrznie inteligencję. Narzuca się więc pytanie: co zapewnia jej wystarczający stopień homogeniczności? Odpowiedź na nie dotyka istoty Mannheimowskiej teorii inteligencji. Socjolog szukał bowiem pewnego wyznacznika inteligenckości. Z przedstawionych wyżej względów odrzucił tezę o podstawowym znaczeniu sytuacji klasowo-ekonomicznej aktora (nie istnieje coś takiego jak klasa inteligencka). To nie wspólny udział w systemie gospodarczym tworzy solidarność grupową tej warstwy:

Istnieje wszakże pewna więź socjologiczna łącząca grupy intelektualistów, choć z klasowego punktu widzenia zbyt wieloznaczna, by można ją było uznać za jedność: właśnie wykształcenie, które łączy je w całkiem nowy sposób. Udział we wspólnych treściach wykształcenia zgodnie $z$ tendencją edukacji zaciera coraz bardziej różnice urodzeniowo-stanowe, zawodowe, majątkowe i łączy poszczególnych wykształconych właśnie pod znakiem tego wykształcenia (Mannheim 2008: 190).

To właśnie „[n] [owoczesne wykształcenie” (tamże: 190) członków omawianej grupy społecznej sprawia, że ich jednostkowe determinacje klasowe znajdują swoją reprezentację $\mathrm{w}$ autonomicznym uniwersum intelektualistów. Dyskurs inteligentów jest mikroświatem społecznych sporów, jest światem polifonii. Spory te sa jednak prowadzone w jednym języku, a problemy dyskutowane na jednej uniwersalnej płaszczyźnie nauki. Może się ona ukształtować dzięki inteligenckiemu wykształceniu, które zapośrednicza jednostce rzeczywistość - m.in. nie angażuje się ona bezpośrednio w stosunki pracy. Światopogląd intelektualisty nie jest w tym samym stopniu uwarunkowany bytowo co świadomość innych grup społecznych. Pojawia się pierwszy paradoks inteligenckiej pozycji społecznej: intelektualista totalny tak naprawdę podważa główną tezę socjologii wiedzy, według której wiedza jest uwarunkowana bytowo. Paradoksalnie, bytowe uwarunko- 
wanie intelektualisty sprawia bowiem dosłownie, że przestaje być on bytowo uwarunkowany. A to dlatego, że świat inteligenckich problemów, niczym Popperowski „trzeci świat” (zob. 2002: 152), jest w pewnym stopniu autonomiczny w stosunku do subiektywnych interesów społeczeństwa, rządzi się własnymi prawami. Podleganie tym prawom stanowi główną więź łącząca intelektualistów. Mimo że świadomość pojedynczego członka tej grupy rozwijała się w ramach pewnego dyskursu klasowego, wykształcenie sprawia, że cechuje się ona „elastycznością ideologiczna”” (Speier 1990: 215). Jeśli chodzi o wybór światopoglądu, myśliciel nie jest niczym skrępowany, może się przez to wczuwać w sytuację różnych aktorów społecznych. Mannheim zaznacza, że „[e]dukacja uczy nas odkrywania naszych własnych spraw w sprawach ludzi od nas dalekich i penetrować punkt widzenia innego człowieka jednocześnie redefiniując nasz" (1956: 119). To jest właśnie definicja Mannheimowskiej empatii. Umożliwia ona interakcję między różnymi punktami widzenia, które moga przez to prowadzić ze sobą dialog, a w konsekwencji dojść do kompromisu (zob. Heeren 1971: 9). Intelektualiści tworzą więc „forum” (Mannheim 2008: 196) - przestrzeń swobodnej deliberacji.

Co ciekawe, opisując powstawanie sfery publicznej Jürgen Habermas bezpośrednio odnosi się do konceptu „społecznie niezakorzenionej inteligencji" (2007: 328) Mannheima (nie wymieniajacc go jednak z nazwiska). Jego zdaniem krystalizacja inteligencji jako odosobnionej warstwy społecznej wiąże się z mieszczańskim odrzuceniem. W czasie burżuazyjnej rewolucji inteligencja była rzecznikiem wyrażającym interes tej awansującej klasy, gdy jednak mieszczaństwo zdobyło dominująca pozycję w społeczeństwie, uznało, że wszelka inteligencka krytyka jest społecznie zbędna, a nawet groźna. Nastapił więc proces izolacji intelektualistów (tamże: 328-329). Habermas wskazuje, że sama idea „oderwanej inteligencji”" (sformułowana zreszta przez samych inteligentów) jest wyrazem iluzji emancypacyjnego charakteru tej izolacji. W przeciwieństwie do Mannheima, który milcząco zakłada, że proces odrywania się inteligencji od społeczeństwa będzie postępował w nieskończoność, autor Strukturalnego przeobrażenia sfery publicz̨nej uważa, że izolacja tej grupy społecznej nie jest permanentna. Trwała przez około sto lat (od połowy XIX wieku) i zakończyła się wraz z upadkiem sfery publicznej (tamże: 329). Trzeba jednak zaznaczyć, że Habermas poświęca mało uwagi samemu problemowi inteligencji, z pewnością nie jest to najważniejszy element jego socjologii historycznej.

Z wszystkich powyższych uwag można wysnuć wniosek, że w ujęciu Mannheima świadomość społeczna kształtuje się na dwóch różnych pozio- 
mach. Pojawia się tutaj wyraźny podział na świat walczących ze sobą klas społecznych oraz świat specjalnej grupy, która usytuowana jest w centrum społeczeństwa (Mannheim 2008: 191). Na czym polega różnica między tymi dwoma poziomami rozumienia rzeczywistości? Można ją unaocznić, powołując się na rozróżnienie, które poczynił Mannheim w jednym ze swoich wczesnych pism. Walczące ze sobą grupy społeczne charakteryzują się „rozumieniem egzystencij” (cyt. za Frisby 2013: 139), a więc sposobem myślenia, który jest bezpośrednio związany $z$ ich uwarunkowaniem bytowym. Ten rodzaj doświadczania świata ma charakter grupowy, rozprzestrzenia się w danym środowisku niczym ,wewnętrzna zaraza" (tamże: 139). Drugi, wyższy poziom poznania to „rozumienie znaczacych całości (pojmowanie znaczenia, intelektualne rozumienie)" (tamże: 139). Mannheim nazywa je interpretacja: jej wykorzystanie pozwala na pokonanie „przedrefleksyjnej” ideologii (tamże: 139) oraz umożliwia jej naukową analizę. Intelektualista musi wzbić się na ten wyższy poziom wiedzy: musi interpretować rzeczywistość naukowymi metodami socjologii wiedzy. To one pozwalają mu na analizę społecznych świadomości przy użyciu wolnego od wartościowania, totalnego konceptu ideologii (Popper 1985: 429).

Według Mannheima ta społeczna pozycja intelektualistów jako ludzi oświeconych uniemożliwia im sięgnięcie po władzę. Gdyby jednak poczuli wolę kontrolowania reszty społeczeństwa, nieuchronnie doprowadziłoby to do faszyzmu (Mannheim 1993: 75). Mannheimowska ,grupa referencyjna" nie jest bowiem tym samym, co marksistowski proletariat. Jak wskazuje Dick Pels, „[i]ntelektualiści [...] powinni być odwiedzeni od myślenia, że są zdolni do uformowania kolektywnej politycznej organizacji «w imię własnego prawa» [Pels cytuje w tym miejscu Mannheima, zob. tegoż 1956: 104 - JK], a zatem nie powinni uważać się za ekwiwalent marksowskiej klasy" (tenże 2003: 94). Intelektualista powinien być przede wszystkim krytykiem, nie zaś politykiem. W związku z tym to, czy jednostkę nazwiemy intelektualistą totalizującym, zależy od dokonanego przez nią wyboru. Mannheim wskazuje na dwie drogi, którymi może ona podążyć: 1) może zaangażować się w walkę klasową z bliską mu warstwą społeczną; 2) druga droga przewiduje przyłączenie się do grupy intelektualistów totalnych i kolektywny „namysł nad własnymi korzeniami, poszukiwanie własnej misji rzecznika predestynowanego do wyrażania interesów całości” (2008: 192). Aby grupowo dotrzeć do społecznej totalności, każdy z intelektualistów musi wybrać druga drogę. Mannheim stawia przed nimi zadanie niemal niemożliwe do wykonania: w czasie skrajnej polaryzacji światopoglądów mają poszukiwać ogólnego interesu społecznego. 


\section{/// 3. Inteligencka totalność}

Widać więc wyraźnie, że socjologia wiedzy broni się przed zarzutami o relatywizm właśnie teoria intelektualisty totalnego. Skoro każdy partykularny „styl myślenia” (Mannheim 1986: 5) pozwala na dostrzeżenie tylko części prawdy, to możliwe jest zsyntetyzowanie tych cząstek, tak by otrzymać prawdę całkowita. Jak już zostało wspomniane, jej wyznacznikiem jest totalność. Mannheim przejął koncepcję totalności najprawdopodobniej od Lukácsa (Jay 1984: 206), a teorię prawdy na niej opartą nazywał „dynamicznym relacjonizmem" (Mannheim 2008: 131). Nawiązania do historyzmu są tutaj ewidentne (Mendel 2006: 30): Mannheimowi nie chodzi bowiem o prawdę uniwersalną, on szuka obiektywności historycznej. Zgodnie z historyzmem przyjmuje, że prawda jest powiązana z okresem historycznym, nie jest wieczna (Loader 1997: 221). Słowami Antonio Gramsciego: obiektywny znaczy w tym przypadku to samo, co „historycznie subiektywny" (cyt. za Salamini 1974: 376). W związku z tym nie można się zgodzić z Mendlem, że w ujęciu Mannheima inteligencja jest „zdolna do zdobycia uniwersalnej prawdy" (Mendel 2006: 32). Prawdą może być tylko historyczna („relacjonistyczna”) totalność (por. Loader 1997: 221). Można jednak zadać pytanie: jaki jest stosunek między partykularnymi świadomościami a totalnością? Jak już zostało wspomniane, Mannheim wskazuje, że perspektywiczne interpretacje nie są po prostu błędne:

Ta partykularność, ta cząstkowość oznacza jednak, że właśnie dziś, kiedy widoczne staje się partyjne uwarunkowanie wiedzy, można z taką samą oczywistością rozpoznać, że tkwi w niej zawsze całość i że aspekty partyjne są uzupełniającymi się cząstkowymi wglądami w całość (2008: 183).

To właśnie intelektualiści totalni dokonują syntezy tych spolaryzowanych cząstek. Ich zadanie to „znaleźć za każdym razem punkt umożliwiający orientację w całości wydarzeń, stróżowanie [podkr. - JK] wśród nader bez tego ciemnej nocy" (tamże: 195). Nie chodzi tutaj o heglowską syntezę absolutną (tenże 1990: 81). Mannheim nazywa historyczne syntezy względnymi lub dynamicznymi. Jednym słowem intelektualiści totalni muszą „dawać widok na całość, możliwie najbardziej wszechstronny w danym czasie" (tenże 2008: 186).

Mannheimowska koncepcja catości nawiązuje oczywiście do Hegla i totalności Ducha Absolutnego. Najdoskonalsza forma ducha charakteryzuje 
się największym stopniem zapośredniczenia. Ujawnia się ona w końcowej fazie procesu, który przeszedł absolut od negacji empirycznej bezpośredniości (Hegel 1965: 423). Heglowska historiozofia postuluje, aby historyczny rozwój tego ducha analizować jako jedną całość, jako proces uświadamiania sobie wolności przez ducha (zob. Mannheim 1990: 79; Bauman 2010: 17). Te dwa heglowskie wątki - spojrzenie na całość procesów historycznych i schemat zapośredniczenia - często pojawiają się w pismach socjologa. Można powiedzieć, że najwyższym stopniem społecznego zapośredniczenia charakteryzuje się świadomość ludzi dobrze wyedukowanych. Wydaje się, że uzasadniona jest następująca analogia: klasowe, cząstkowe świadomości byłyby odpowiednikiem heglowskiej bezpośredniości. W wyniku zdobycia wykształcenia przez intelektualistę, a tym samym możliwości wczuwania się w różne perspektywy, w jego świadomości jedna bezpośredniość zostaje zanegowana przez inne. Parafrazując Hegla, można powiedzieć, że każda grupa ma swoje społeczne „tu” lub „teraz” (Hegel 1963: 117-118). Grupowy światopogląd intelektualistów przechodzi przez całą serię takich negacji (konfrontacji z innymi klasowymi światopoglądami), aż stanie się zdolny do oglądu totalności. Nie jest to równoznaczne z postawieniem się poza podmiotem i spojrzeniem na niego okiem empirysty. To właśnie pozycja społeczna intelektualisty pozwala na dialektyczne zniesienie różnicy między podmiotem a przedmiotem. Społeczeństwo i intelektualista stanowią jedność, której momentami są syntezy bliskości i oderwania. Loader opisuje tę dialektykę następująco: „[d]ystans znaczy refleksyjność $[\ldots]$ przez postawienie się jako przedmiot w kontekście, tak że jest się zarówno przedmiotem, jak i podmiotem” (2016: 56). Pozwala to inteligencji na obiektywną analizę społeczeństwa, którego jednocześnie jest częścią. Refleksyjność zakłada spojrzenie zarówno na siebie, jak i na przedmiot z poziomu totalności: według socjologa „[t]ylko ten może opanować sytuację, kto spojrzy poza nią" (Mannheim 1956: 120). Możliwość postawienia się na miejscu kogoś innego jest tym, co Mannheim nazywa inteligenckim „impulsem transcendowania” (1956: 164). Konkludując, intelektualista nie ma dostępu do rzeczywistości samej w sobie, może jedynie syntetyzować perspektywiczne interpretacje bytu i tym samym dostrzec całość systemu społecznego.

Mannheimowskie odcięcie się od marksistowskiej dialektyki wydaje się w tym miejscu ewidentne. Chociaż socjolog zastrzega, że chodzi mu o „totalność tego świata, a nie totalność sfery konceptów abstrakcyjnych" (cyt. za Frisby 2013: 135), to wydaje się, że jego teoria jest niejako powrotem do Hegla. Jak zauważa Max Horkheimer, w teorii Mannheima sprzeczności 
świata społecznego zostają dialektycznie zniesione w dziedzinie myśli (Jay 1984: 208). Świadomość grupowa intelektualistów totalnych (zaopatrzona w socjologię wiedzy, zob. Pels 2003: 84) jest areną, na której rozwiązane zostają sprzeczności (por. Świrek 2018: 205), podmiot nie musi oddawać się żadnej rewolucyjnej praktyce. Oczywiste staje się więc, dlaczego Mannheima nazywano „burżuazyjnym Lukácsem” (cyt. za Loader 1985: 96). W tym określeniu przymiotnik ma zasadnicze znaczenie. Jak zauważa Speier, „Mannheima «synoptyczna orientacja» [...] różni się od Marksowskiej «intuicji totalności»" (1990: 220, por. Mészáros 1972: 64). Cechą intelektualistów totalnych jest ich wspólna umiejętność sięgnięcia totalności, co prowadzi Mannheima do kompromisowego wniosku: grupa intelektualistów totalnych składa się po prostu z ,[...] bardziej refleksyjnych rzeczników każdej z grup społecznych" (Jay 1984: 207). Jak dowodzi Krzysztof Świrek, Mannheim sytuuje inteligencję w pozycji społecznie neutralnej, przez co jej ogląd świata przestaje mieć charakter krytyczny (2017: 75). Ta teza Świrka koresponduje z moim spostrzeżeniem o performatywnym oddzieleniu dwóch poziomów świadomości społecznej przez socjologa: inteligencka „obiektywność” odgrodzona zostaje od klasowej „nieświadomości społecznej” (Mannheim 2008: 71).

\section{/// 4. Obcość - psychologia inteligencji}

Wzbicie się na ten historycznie obiektywny poziom możliwe jest tylko dzięki zdystansowaniu się do codziennego biegu życia. Psychologiczne i socjologiczne skutki takiego społecznego oddalenia można unaocznić, powołując się na esej Georga Simmla pt. Obcy. Droga do oglądu totalności wiąże się z tym, co w kontekście społecznej sytuacji cudzoziemca Simmel nazywa „momentem wykluczenia” (2006: 205). W teorii Mannheima byłby to etap, w którym członek inteligencji opuszcza środowisko swojej dawnej klasy, za co spotyka go grupowy ostracyzm. Jak podkreśla socjolog, ,[w] jakimś sensie intelektualiści to renegaci, którzy porzucili swoją rodzicielską warstwę" (1956: 143). Aplikując terminologię Simmla do analizy problemu inteligencji, można więc powiedzieć, że intelektualista jest obcym, „osobą bez własnego miejsca” (2006: 206). Niczym Simmlowski przyjezdny nie jest on pełnoprawnym członkiem danej społeczności, a jednak w niej uczestniczy. Można powiedzieć, że intelektualiści totalni lawirują na granicy społeczeństwa - są dla wspólnoty jednocześnie kimś bliskim i dalekim. Jednym słowem: jako obcy grupa ta „reprezentuje syntezę bliskości i oddalenia" (tamże: 206). 
Wraz z postępującym oddalaniem się intelektualisty od społeczeństwa jego kontakt z członkami wspólnoty staje się przygodny. W pewnym stopniu dystansuje się on od ich problemów, przez co jego obraz społeczeństwa nabiera bardziej obiektywnego charakteru. Nigdy nie przywiązuje się do jednego punktu widzenia: jest jak Simmlowska „osoba ruchliwa”, która „styka się przypadkowo z każdym elementem, z żadnym jednak nie łączą jej trwałe [...] więzi” (Simmel 2006: 207). Grupa takich wolnych jednostek może uzyskać dostęp do historycznej obiektywności, albowiem ich światopogląd nie jest skorumpowany przez klasowe interesy. Simmel zauważa, że „[o]biektywność nie jest bynajmniej zaprzeczeniem uczestnictwa [...], ale szczególnym pozytywnym rodzajem uczestnictwa" (tamże: 208). W przypadku intelektualisty totalizującego jest to uczestnictwo opierające się na zasadzie dobrowolności, co sprawia, że więź łącząca go z grupa ma charakter bardziej abstrakcyjny i ogólny. „Obiektywność można też określić jako wolność" (Simmel 2006: 208), w kontekście teorii Mannheima byłaby to wolność do krytyki: „obcy ma większą swobodę praktyczną i teoretyczna, obserwuje sytuację bardziej bezstronnie, ocenia ją, stosując bardziej ogólne i obiektywne kryteria, w swym działaniu pozostaje nie skrępowany przyzwyczajeniem, nabożnym szacunkiem ani tradycją" (tamże: 208). Wydaje się, że wszystkie te cechy obcego można również przyporządkować intelektualiście totalizującemu. Jako wolna jednostka może krytykować zarówno istniejącą władzę, jak i jednostronne programy społecznych utopii.

Według Mannheima, ta intelektualistyczna obcość zaczęła się uwidaczniać już w czasach, w których omawiana warstwa brała aktywny udział w walce klasowych świadomości. Jak wskazuje John Heeren, „,sojusz między intelektualistami a poszczególną klasą zawsze był niełatwy, zawsze charakteryzował się nieufnością spowodowana społecznymi i psychologicznymi różnicami między nimi” (1971: 6). Przyczyna wspomnianej nieufności jest prosta: inteligencja nigdy nie mogła całkowicie stopić się z daną klasa, ponieważ wiązałoby się to z rodzajem autodegradacji (zob. Mannheim 2008: 193), byłby to więc związek sztuczny. Intelektualiści totalni powinni pogodzić się z tym, że są społecznie niezakorzenieni. Oczywiście nie jest to łatwe zadanie, z poczucia ciagłej obcości i zagubienia wynikaja różne specyficzne cechy intelektualistów: z jednej strony ich radykalizm (tamże: 193), zaś z drugiej - podejrzliwość wobec wszelkich totalizujących dyskursów. Hannah Arendt uogólnia tę druga obserwację i wskazuje, że socjologia wiedzy jest nieufna wobec wszelkich tworów duchowych: „Bezdomność i ewidentny brak przywiązania [...] budzi podejrzenie w stosunku do wszystkiego co duchowe" (1990: 200). Mamy więc do czynienia z dwo- 
ma stronami inteligenckiej obcości: wynika ona z nieufności społeczeństwa w stosunku do obcego oraz nieufności intelektualisty w stosunku do społeczeństwa i jego wytworów duchowych. Właśnie dlatego Mannheim nazywa intelektualistów „outsiderami” (1956: 133) - ich sfera aktywności cechuje się daleko posuniętą autonomią, co sprawia, że wymykają się prostej klasyfikacji (np. podziałowi ról społecznych czy podziałowi pracy).

Pomimo wspomnianych wcześniej różnic między koncepcjami Mannheima i Bourdieu w omawianej kwestii można zauważyć pewne podobieństwo (przy założeniu, że zapominamy o demaskatorskim stosunku Bourdieu do figury intelektualisty totalnego). Bourdieu wskazuje, że ,[t]en dystans względem wszystkich ustalonych pozycji oraz tych, którzy je zajmuja [...], jest momentem określającym «intelektualistę wolnego»" (2001: 325). Zarówno Sartre, jak i intelektualista totalizujący są wolni, jeśli chodzi o wybór pola społecznego, na którym chcą działać, wyłamuja się przez to społecznej determinacji, przy czym Bourdieu nazywa to iluzją niezdeterminowania (1980) i wskazuje, że wolność jest raczej subiektywnym odczuciem intelektualisty totalnego, nie zaś - jak w przypadku teorii Mannheima - obiektywnym wynikiem procesu historycznego.

Tak więc intelektualiści totalni żyją w sytuacji problematycznej: istnieje u nich , rozdźwięk między powiązaniem duchowym a społecznym” (Mannheim 2008: 296). Codzienność przybliża ich (jako jednostki) do społeczeństwa, wykształcenie każe im zachować wobec niego dystans (Mendel 2006: 38, por. Pels 2003: 81) i zwrócić się w stronę grupowego inteligenckiego rozumu. W tym napięciu uwidacznia się tragiczna pozycja intelektualistów, którzy wyrażają interes catości. Z jednej strony są oni niewolnikami historii, stali się ofiarami „oderwania” - zostali grupowym „apostatą” (Mannheim 1956: 143), z drugiej strony, muszą wspólnie tę sytuacje wykorzystać - ciąży na nich ogromna odpowiedzialność. Muszą żyć w społeczeństwie, które stale wypycha ich poza swoje granice.

Wszystko to sprawia, że droga wiodąca do oglądu totalności jest długa i uciążliwa, a zaczyna się - jak to już zostało wspomniane na wstępie - na poziomie jednostkowym, w momencie, w którym młody członek inteligencji zda sobie sprawę, że jego świat społeczny jest tylko jednym z wielu istniejących światów (tamże: 164). W relację podmiotu ze światem wdziera się wówczas obcość (Marotta 2012: 680). Odkrycie tego relatywnego charakteru społecznej bezpośredniości jest najważniejszym momentem socjologicznego oświecenia: każdy świat społeczny okazuje się hipostaza pewnego partykularnego światopoglądu. Oświecenie wymaga „ucieczki” od tych wszystkich uniwersalizacji - pozostanie duchowo bezdomnym 
wydaje się najbezpieczniejszą strategia. Według Mannheima dojście do takiego stanu mentalnego może wiązać się z problemami psychicznymi, m.in. z introwertyzmem, a nawet ze schizotymia. To drugie schorzenie wydaje się symptomatyczne: jest wywołane przez antagonizm między wewnętrznym imperatywem jednostki a prawami rządzącymi zewnętrznym światem. Tragizm sytuacji intelektualisty bardzo dobrze oddaje fragment wykładu, który Mannheim wygłosił do grupy młodych socjologów:

Tylko ten, kto, jako intelektualista, zdał sobie sprawę z faktu, że jako osoba wykształcona jest szanowany bardziej niż wszyscy inni, ale jest niczym w oczach burżuazji i proletariatu, że wie wszystko i nie może zrobić nic, że wszyscy go potrzebują i że pomimo to jest on odrzucany - tylko taka osoba jest w stanie nie tylko dojść do generalnej teorii niemocy ducha, ale również uznać ją za los całej warstwy społecznej, i w związku z tym zrozumieć siebie jako produkt sytuacji społecznej (cyt. za Kettler, Meja 1995: 129).

W powyższym cytacie silnie wybrzmiewa motyw autobiograficzny. Wielu badaczy wskazywało, że Mannheim jako intelektualista-socjolog wiedzy stanowi pierwowzór dla swojej własnej teorii (zob. Korczyński 2017: 194; zob. krytykę socjologicznego hipostazowania intelektualistów w: Popper 1985: 431). Silny nacisk na alienację znajdziemy zarówno w teorii inteligencji, jak i w jego prywatnych dokumentach. Wynika z nich bowiem, że „Mannheim był socjologicznym nomada” (Pels 2003: 82). Mimo to myśliciel nie zgadzał się na polityczną izolację intelektualistów, chciał zaangażować ich w proces pracy na rzecz społeczeństwa (Woldring 1986: 217). Dick Pels zaznacza, że „[s]am Mannheim wyraźnie połączył «socjologiczny imperatyw» $z$ własną sytuacją życiowa jako badacza, wprowadzając nawet wyobcowanie jako kryterium socjologicznego oświecenia” (2003: 84).

\section{/// 5. Społeczna rola intelektualistów - podsumowanie}

Obcość intelektualisty nie sprawia bynajmniej, że jego zaangażowanie może odnosić się jedynie do sfery pozapolitycznej. Wręcz przeciwnie. Według Mannheima najgorszą drogą, którą mógłby obrać intelektualista, byłoby zamknięcie się w czczych spekulatywnych rozważaniach. Mannheim wskazuje, że „[j]est całkowicie niezbędne, aby intelekt stał się bojowy” (1993: 79), zaangażowanie polityczne jest więc wskazane. Sa jednak pewne warunki określające charakter działań politycznych: w związku z tym, 
że intelektualista może kształtować swój światopogląd w sposób wolny, jego wybór polityczny musi być poprzedzony naukową i obiektywną analizą sytuacji społecznej. Decyzja o przyłączeniu się do walki po stronie konkretnej klasy musi opierać się na - wyżej omówionej - socjologicznej interpretacji rzeczywistości (Mannheim 2008: 194).

Nawiązanie do Webera jest tutaj ewidentne: intelektualiści pochodzą z różnych środowisk, mają różne poglądy polityczne i wyznają różne wartości, ale wraz ze zdobyciem wykształcenia sa zobligowani do naukowej analizy społeczeństwa (por. Weber 1985: 84), tak aby wspólnie wypracować jego obiektywny obraz. Mannheimowi nie chodzi jednak o Weberowska obiektywność osiągniętą dzięki wolnej od wartościowania analizie przedmiotu, ale o obiektywność, która jest wynikiem wielu jednostkowych wartościowań wpisanych w szerszą całość (intelektualista nie może uwolnić się od wartościowania - może jedynie zdać sobie sprawę z jego partykularności). Zasadnicza różnica między tymi dwoma podejściami sprowadza się więc do faktu, że w teorii Webera to pojedynczy naukowiec może zapewnić sobie dostęp do obiektywności, zaś w koncepcji Mannheima dostęp ten zarezerwowany jest wyłącznie dla całej grupy intelektualistów. Badacz nie zgadzał się z Weberowskim odpolitycznieniem naukowca, inteligencka synteza miała dla niego charakter polityczny (Loader, Kettler 2002: 90-91). To właśnie zaangażowanie polityczne intelektualisty pozwala mu na „doświadczenie” partykularności swojego własnego światopoglądu, albowiem, jak starałem się pokazać w niniejszym artykule, kluczową rolę w socjologii Mannheima odgrywa samopoznanie (zob. tamże: 91). Według Mannheima Weber skonstruował teoretyczny mur oddzielający naukę od działania praktycznego. Nauka była dla niego sferą czysto uniwersytecka, nie miała konsekwencji politycznych (Weber 1999: 210). Mannheim chciał zespolić odosobnionego naukowca Weberowskiego typu z rzeczywistościa pozauniwersytecka (Loader 1985: 122; Kettler, Meja, Stehr 1990: 1458). Polityczne zaangażowanie stanowi więc część misji, która została powierzona intelektualiście totalizującemu, jego wiedza „nie jest [...] udowodniona przez «obserwację», ale przez «aktywną partycypację»" (Frisby 2013: 160). Ta wiedza stanowi podstawę dla trzech ról społecznych, które pełni intelektualista. Mannheim obrazuje je za pomocą metafor. Pierwsza z nich pojawiła się już w niniejszym artykule. Według niej intelektualiści totalni są nocnymi stróżami pilnującymi społeczeństwa podczas ciemnej nocy. Jest to więc rola prewencyjna: sprowadza się do podważania wszystkich jednostronnych dyskursów oraz wykazywania ich partykularności (powiązania bytowego). Druga metaforę Mannheim przedstawia w formie pytania re- 
torycznego: „,W ostateczności, czy intelektualista nie jest zaledwie pianą na grzbiecie fali?" (1956: 169). Implikuje ona zaangażowanie intelektualisty w przewidywanie biegu historii oraz ukierunkowywanie działań społeczeństwa, tak by podążało w dobrą stronę (por. Mannheim 2008: 188). Byłaby to więc rola społecznego doradcy. Granice tego doradztwa Mannheim ukazuje przy pomocy trzeciej, psychoanalitycznej metafory. Intelektualiści, niczym diagności, nie moga sprawować bezpośredniej kontroli nad pacjentem, którym jest społeczeństwo, nie moga zmusić go do pewnych działań (jak już zostało wskazane - prowadziłoby to do faszyzmu). Mogą natomiast zadawać mu pytania, unaoczniać kompleksy, ukazywać różne możliwości działań (Kettler, Meja, Stehr 1990: 1458) - słowami Poppera - poddawać go „socjoterapii” (1985: 429). Jest to więc rola terapeuty, nie zaś rewolucjonisty.

Podsumowując, intelektualiści totalni to część inteligencji, która wsłuchuje się w historię. Akceptuje swoją tragiczną pozycję i nie stara się sztucznie przypodobać konkretnej klasie społecznej. W czasach bezwzględnej walki świadomości za pomoca refleksji oraz pracy intelektualnej próbuje odnaleźć ogólny interes społeczeństwa. Powracając do postawionego na wstępie problemu odróżnienia inteligenta od intelektualisty, można zauważyć, że to sam przedmiot zainteresowania zmusza Mannheima do lawirowania między indywidualnym a kolektywnym poziomem analizy (z silniejszym naciskiem na ten drugi). Intelektualiści zdobywają wykształcenie indywidualnie, jako jednostki, jednak skutek tego procesu zbliża ich do siebie: zostają odrzuceni przez społeczeństwo, uznaje się ich za obcych, a to sprawia, że upodabniają się do siebie. Obcość i wykształcenie umożliwiaja im oddanie się wolnej refleksji i to ona wyróżnia intelektualistę totalizującego od przeciętnego inteligenta. Na tej podstawie uzasadnione wydaje się więc skonstruowanie kategorii (opartej na teorii Mannheima) intelektualistów totalnych: „Nie chodzi tu o posiadaczy dyplomów, lecz o tych nielicznych intelektualistów w ich szeregach, którzy zawsze świadomie czy nieświadomie, pragnęli czegoś innego niż tylko przeskoczenia na wyższy stopień społecznego bytu" (2008: 295). To rewolucyjne utopie chca przyspieszyć bieg historii, pragną wszystko zmienić, zburzyć stary świat. Intelektualistyczne „coś innego” to właśnie refleksja: podejmowanie decyzji opiera się w tym przypadku na totalnym oglądzie społeczeństwa. 
Bibliografia:

/// Arendt H. 1990. Philosophy and Sociology, [w:] Knowledge and Politics: The Sociology of Knowledge Dispute, red. V. Meja, N. Stehr, Routledge, s. 196-208.

/// Bauman Z. 2010. Hermeneutics and Social Science: Approaches to Understanding, Routledge.

/// Bourdieu P. 1980. Sartre. https://www.lrb.co.uk/the-paper/v02/n22/ pierre-bourdieu/sartre; dostęp: 21.03.2020.

/// Bourdieu P. 2001. Aneks: Intelektualista totalny i ilurja wszechmocy, [w:] tegoż, Reguly sžtuki. Geneza $i$ struktura pola literackiego, tłum. A. Zawadzki, Universitas, s. 321-327.

/// Chałasiński J. 1946. Społecæna genealogia inteligencji polskiej, Spółdzielnia Wydawnicza „Czytelnik”.

/// Domański H. 2008. Wstęp, [w:] Inteligencja w Polsce: specjaliści, twórcy, klerkowie, kelasa średnia?, red. H. Domański, Wydawnictwo IFiS PAN.

/// Epstein M. 2018. Intelligentsia, intellectuals, and the social functions of intelligence, „Russian Journal of Communication”, vol. 10, nr 2-3, s. 165-181.

/// Frisby D. 2013. The Alienated Mind: The Emergence of the Sociology of Knowledge in Germany (1918-1933), Routledge.

/// Habermas J. 2007. Strukturalne przeobrażenia sfery publicznej, tłum. W. Lipnik, M. Lukasiewicz, Wydawnictwo Naukowe PWN.

/// Heeren J. 1971. Karl Mannheim and the Intellectual Elite, „The British Journal of Sociology", vol. 22, nr 1, s. 1-15.

/// Hegel G.W.F. 1963. Fenomenologia ducha, t. 1, ttum. A. Landman, PWN.

/// Hegel G.W.F. 1965. Fenomenologia ducha, t. 2, tłum. A. Landman, PWN.

/// Jay M. 1984. Marxism and Totality: The Adventures of a Concept from Lukács to Habermas, University of California Press.

/// Kecskemeti P. 1952. Introduction, [w:] Karl Mannheim, Essays on the Sociology of Knowledge, Routledge, s. 1-32.

/// Kettler D., Meja V. 1995. Karl Mannheim and the Crisis of Liberalism: The Secret of These New Times, Transaction Publishers. 
/// Kettler D., Meja V., Stehr N. 1990. Rationalizing the Irrational: Karl Mannheim and the Besetting Sin of German Intellectuals, „American Journal of Sociology", vol. 95, nr 6, s. 1441-1473.

/// Korczyński T. 2017. Karl Mannheim jako Swój-Obcy-Wróg w teorii zwrotu inkorporacyjnego, [w:] Wspótcresne problemy socjologii wiedzy. W 80-lecie „Ideologii i utopii” Karla Mannheima, red. M. Dziobkowski, Warszawskie Wydawnictwo Socjologiczne, s. 189-198.

/// Kozubowski J. 2018. Ciagtość czy zerwanie? Præyczynek do rožważań na temat historii polskiej myśli socjalistycznej dziewietnastego wieku, „Praktyka Teoretyczna", nr 3(29), s. 51-77.

/// Loader C. 1985. The Intellectual Development of Karl Mannheim: Culture, Politics, and Planning, Cambridge University Press.

/// Loader C. 1997. Free Floating: The Intelligentsia in the Work of Alfred Weber and Karl Mannheim, „German Studies Review”, nr 20(2), s. 217-234.

/// Loader C. 2016. The Cultural Sociology of Alfred Weber and Karl Mannheim, [w:] The SAGE Handbook of Cultural Sociology, red. D. Inglis, A. Almila, SAGE, s. 48-59.

/// Loader C., Kettler D. 2002. Karl Mannheim's Sociology as Political Education, Routledge.

/// Mannheim K. 1943. The Crisis in Valuation, [w:] tegoż, Diagnosis of Our Time: Wartime Essays of a Sociologist, Kegan Paul, s. 31-53.

/// Mannheim K. 1952. Historicism, [w:] tegoż, Essays on the Sociology of Knowledge, Routledge, s. 84-133.

/// Mannheim K. 1956. The Problem of the Intelligentsia. An Inquiry into Its Past and Present Role, [w:] tegoż, Essays on the Sociology of Culture, Routledge, s. 91-171.

/// Mannheim K. 1986. Myśl konserwatywna, tłum. S. Magala, Kolegium Otryckie.

/// Mannheim K. 1990. Competition as a Cultural Phenomenon, [w:] Knowledge and Politics: The Sociology of Knowledge Dispute, red. V. Meja, N. Stehr, Routledge, s. 53-85.

/// Mannheim K. 1993. The Sociology of Intellectuals, tłum. D. Pels, „Theory, Culture \& Society", vol. 10, nr 3, s. 69-80. 
/// Mannheim K. 2008. Ideologia i utopia, tłum. J. Miziński, Wydawnictwo „Aletheia”.

/// Marotta V. 2012. Georg Simmel, the Stranger and the Sociology of Knowledge, „Journal of Intercultural Studies”, vol. 33, nr 6, s. 675-689.

/// Mendel I. 2006. Mannheim's Free-Floating Intelligentsia: The Role of Closeness and Distance in the Analysis of Society, „Studies in Social and Political Thought", nr 12, s. 30-52.

/// Mészáros I. 1972. Ideology and Social Science, „Socialist Register”, nr 9, s. $35-81$.

/// Peciakowski T. 2016. Wédrujace pojecia czy zjawiska? O podróżach pojéc na przyktadzie ,intelektualisty”, „Stan Rzeczy”, nr 1(10), s. 258-282.

/// Pels D. 2003. The Intellectual as Stranger: Studies in Spokespersonship, Routledge.

/// Popper K. 1985. Socjologia wiedzy, tłum. A. Chmielecki, [w:] Problemy socjologii wiedzy, red. A. Chmielecki, PWN, s. 426-440.

/// Popper K. 2002. Epistemologia bezpodmiotu poznajacego, [w:] tegoż, Wiedza obiektywna. Ewolucyjna teoria epistemologiczna, tłum. A. Chmielewski, Wydawnictwo Naukowe PWN, s. 148-206.

/// Rousseau J.-J. 1956. Czy odrodzenie nauk i sqtuk przyczynito sie do poprawy obyczajow?, [w:] tegoż, Trzy rozprawy z filozofii spotecznej, tłum. H. Elzenberg, PWN.

/// Sadri A. 1992. Max Weber's Sociology of Intellectuals, Oxford University Press.

/// Salamini L. 1974. Gramsci and Marxist Sociology of Knowledge: An Analysis of Hegemony-Ideology-Knowledge, „The Sociological Quarterly”, nr 3, s. 359-380.

/// Simmel G. 2006. Obcy, [w:] tegoż, Most i drazwi: wybór esejón, tłum. M. Łukaszewicz, Oficyna Naukowa, s. 204-212.

/// Speier H. 1990. Sociology or Ideology? Notes on the Sociology of the Intelligentsia, [w:] Knowledge and Politics: The Sociology of Knowledge Dispute, red. V. Meja, N. Stehr, Routledge, s. 209-222.

/// Świrek K. 2017. Pojecie ideologii jako pojecie krytyczne, „Przegląd Humanistyczny", nr 61, s. 63-77. 
/// Świrek K. 2018. Karol Marks i problem przyszłości, „Stan Rzeczy”, nr 1(14), s. 203-226.

/// Szczepański J. 1991a. Intelektualisci, [w:] Encyklopedia kultury polskiej XX wieku. Pojecia i problemy wiedzy o kulturze, red. A. Kłoskowska, Wiedza o Kulturze.

/// Szczepański J. 1991b. Inteligencja, [w:] Encyklopedia kultury polskiej XX wieku. Pojecia i problemy wiedzy o kulturze, red. A. Kłoskowska, Wiedza o Kulturze.

/// Walicki A. 2011. „Filozofia narodowa” i poczatek sporu o samookreślenie i powotanie inteligencji polskiej, [w:] tegoż, Polska, Rosja, marksiz̨m, Universitas, s. 9-29.

/// Weber M. 1985. „Obiektymnosí”” poznania w naukach społecznych, tłum. M. Skwieciński, [w:] Problemy socjologii wiedzy, red. A. Chmielecki, PWN, s. $45-100$.

/// Weber M. 1999. Nauka jako zawód i powołanie, tłum. P. Dybel, [w:] M. Weber, red. Z. Krasnodębski, Wiedza Powszechna, s. 199-217.

/// Wójcik B. 2014. Dialektyka utopii, „Estetyka i Krytyka”, nr 35, s. 49-72.

/// Woldring H.E.S. 1986. Karl Mannheim: The Development of His Thought; Philosophy, Sociology and Social Ethics, with a Detailed Biography, Van Gorcum.

\section{/// Abstrakt}

W artykule zaprezentowano koncepcję inteligencji Karla Mannheima oraz usytuowano ją w kontekście teorii wiedzy socjologa. We wstępnej części pracy dookreślone zostały terminy wykorzystywane przez Mannheima. Na podstawie teorii socjologicznej przedstawiono znaczenie pojęć „inteligencja” oraz „intelektualiści”. Sławna teza o istnieniu „względnie oderwanej inteligencji” opiera się na założeniu, że ta wyróżniona warstwa społeczna nie uczestniczy bezpośrednio w walce grupowych świadomości (utopii $\mathrm{i}$ ideologii). W ramach procesu historycznego nastąpiła jej alienacja, umożliwiło jej to dostrzeżenie historycznie zdeterminowanej prawdy. Część inteligencji, która wypełnia swoją misję poszukiwania tej prawdy, zostaje w artykule nazwana intelektualistami totalnymi, posiada ona bowiem zdolność oglądu totalności społeczeństwa. W pracy przeanalizowano koncepcję totalności oraz jej heglowskie źródła. Dystans wobec problemów społeczeństwa klasowego, który jest skutkiem nowoczesnego wykształcenia intelek- 
tualisty, pozwala mu na eksplorację pełnego obrazu różnych ścierających się światopoglądów. Wykształcenie sprawia jednak, że staje się on obcym elementem dla społeczeństwa. Ta cecha intelektualisty została omówiona przez pryzmat eseju Georga Simmla pt. Obcy. W końcowej części artykułu poruszony został problem społecznej roli intelektualistów totalnych, którzy pomimo swojego odosobnienia powinni zaangażować się w politykę i przyjąć na siebie rolę społecznego doradcy.

Słowa kluczowe:

Karl Mannheim, intelektualiści totalni, inteligencja, totalność, obcy, Weber

\section{/// Abstract}

Total Intellectuals as Representatives of the Intelligentsia - Karl Mannheim's Theory of the "Free-Floating" Stratum

This article concerns Karl Mannheim's theory of the intelligentsia and its importance for his sociology of knowledge. The terms used by Mannheim are defined in the introductory part of the article. The meaning of the words "intelligentsia" and "intellectuals" are based on diverse sociological theories. The famous concept of a "relatively unattached intelligentsia" derives from the assumption that this social stratum does not participate directly in the struggle between different group consciousnesses (utopias and ideologies). As a result of historical processes it became alienated from society and was thus able to gain a wider understanding of historical truth. In the article, the type of intellectual who is seeking this truth is called a total intellectual, because such a person has the ability to see society as a totality. The concept of totality and its Hegelian sources are also analysed in the paper. Being distanced from the problems of class society is a result of modern education and allows the intellectual to explore the holistic picture of the struggle between different worldviews. However, because of their education, intellectuals are seen as a foreign element in society. This feature of the intelligentsia is discussed in reference to Georg Simmel's essay "The Stranger." The final part of the article deals with the problem of the social role of total intellectuals, who should try to become engaged in politics despite their isolated position.

Keywords:

Karl Mannheim, total intellectuals, intelligentsia, totality, stranger, Weber 
/// Jan Kozubowski - student Kolegium Międzydziedzinowych Indywidualnych Studiów Humanistycznych i Społecznych UW. Aktualnie bada powiązania między socjologia wiedzy a marksizmem. Jego szczególnym zainteresowaniem ciesza się teorie Karla Mannheima oraz Györgya Lukácsa. Autor artykułu pt. Ciagtość cæy zerwanie? Prそyczynek do roz̨ważań na temat historii polskiej myśli socjalistycznej dzৃiewiętnastego wieku, który ukazal się w „Praktyce Teoretycznej” w 2018 roku.

ORCID: https://orcid.org/0000-0003-1214-2180

E-mail:kozubowskijan@gmail.com 